\title{
İnşaat Yıkıntı Atıkları İle İyileştirilmiş Yol Alt Dolgularının FLAC 2D ile Analizi
}

\author{
Mehmet Tahsin BILGIÇLi $\dot{I}^{1}$, İsa VURAL ${ }^{2}$ \\ 1. Sakarya Uygulamalı Bilimler Üniversitesi, Lisansüstü Eğitim Enstitüsü, Yüksek Lisans, Sakarya, Türkiye \\ 2.Sakarya Uygulamalı Bilimler Üniversitesi Teknoloji Fakültesi İnşaat Mühendisliği Bölümü, Sakarya, Türkiye
}

\section{Özet}

Türkiye'de inşaat yıkıntı atıklarını, gece kondu alanları, depremde yıkılmış alanlar, dekoratif ve mimari yenilik amaçlı çalışmalar, ağır hasar görmüş binalardan kaynaklı atıklar oluşturmaktadır. İSTAC ve İBB' nin yaptığı çalışmalar sonucunda inşaat sektöründe kullanılacak malzeme miktarının ortalama \%35'i kadar beton atık oluşması beklenmektedir. Gelişen nüfus şartları atık miktarını her geçen gün arttırmakta ve depolanması sonucu belirli çevresel etkileri beraberinde getiren inşaat yıkıntı atıklarının kullanılması için çalışmaların yapılmasını zorunlu hale getirmektedir. Atıkların kullanımı ile depolama ihtiyacı ortadan kalkacak ve depolama için ayrılacak sahalar başka amaçlar için kullanılabilecektir. Kullanımın artması sonucu atık malzemelerin oluşturduğu çevresel etkiler azalacaktır. Ayrıca bazı tükenmekte olan veya pahalı doğal malzemelerin yerine kullanılarak ekonomik ekosistem açısından avantajlı olacaktır. Bu çalışmada inşaat yıkıntı atıklarının yol inşaatı alt yapı iyileştirme çalışmalarında kullanılabilirliği araştırılmıştır. Zemin özellikleri belirlenmiş bir yol güzergâhında zemin tabakaları ve parametreleri FLAC 2D ile modellemiş, çıkan zemin oturma değerleri sonucu mevcut zeminin beklenen taşıma gücüne sahip olmadığı görülmüsstür. Yüzeye yakın olan zayıf zemin alanı boşaltılarak yerine laboratuar deneyleri sonucu zemin değerleri belirlenmiş inşaat yıkıntı atıklarının parametrelerinin FLAC 2D ile modellemesi yapılmıştır. Yapılan analiz sonucunda zemin oturma değerinde inşaat yıkıntı atıkları ile yapılan iyileştirmede $\% 84$, kazık destekli sistemde ise \%95 iyileşme olduğu belirlenmiştir.

Anahtar kelimeler: Zemin iyileştirme, inşaat yıkıntı atıkları, alt temel malzemesi, FLAC 2D

\section{FLAC 2D Analysis Of Improved Road Sub-Base With Construction Wastes}

\section{Summary}

The construction waste in Turkey are occur from residential areas, areas destroyed by earthquakes, works for decorative and architectural innovation and wastes from heavily damaged buildings. It is expected that $35 \%$ of the materials to be used in the construction sector will be occur concrete wastes as a result of the work done by ISTAC and IMM. Developing population conditions increase the amount of waste day by day and bring with it certain environmental impacts as a result of storage Thus, it makes it necessary to carry out works for the use of construction waste. With the use of wastes, the need for storage will be eliminated and the sites to be allocated for storage may be used for other purposes. The increase of use will reduce the environmental impacts of waste materials and also it would be advantageous for the economic ecosystem by replacing some of the depleted or expensive natural materials. In this present work, usability of construction demolition wastes in road construction infrastructure improvement studies was investigated. Soil layers and parameters were modeled with FLAC 2D on a road route with determined soil properties. The weak ground area near the surface was evacuated and the parameters of construction demolition wastes (construction demolition wastes) were determined by FLAC 2D. As a result of the analysis, it was determined that $84 \%$ improvement was achieved in the ground settlement value and $95 \%$ improvement in the pile-supported system.

Keywords: Soil improvement, construction demolition waste, sub-base material, FLAC 2D

*Corresponding author: Address: Faculty of Engineering, Department of Civil Engineering Sakarya University, 54187, Sakarya TURKEY. E-mail address: ivural@ sakarya.edu.tr, Phone: +902642956479 


\section{Giriş}

Zemin iyileştirme tekniklerine; yol yapısının statik yükleri altında istenen performansı gösteremeyeceği anlaşılan zeminler de sık ihtiyaç duyulmaktadır. İyileştirilecek zeminlerin; niteliği, kalınlığı, zamana bağlı oturma özellikleri, stabiliteyi etkileyecek kayma dayanım parametreleri, şişme potansiyeli belirlenmekte ve bu sonuçlara göre iyileştirme yöntemi tercih edilmektedir. Zemin yüzeyine yakın tabakaların yapı yüklerini, göçmeden veya aşırı oturmalar meydana gelmeden taşıyamadığı durumlarda dolgu ile zemini iyileştirme tercih edilmektedir. Yapılması planlanan yolun projelendirilmesinde göçmeye karşı yeterli güvenliğin bulunduğu; ayrıca servis yüklerinin meydana getireceği oturmaların kabul edilebilir bir sınırı aşmadığı gösterilmelidir[1]. Gelişmekte olan ülkelerde ciddileşen sorunların başında atık maddelerin tekrar kullanılması gelmektedir. Kentlerdeki büyüme, artan nüfus koşulları ve çevresel sağlık problemlerinin artış göstermesi düşük maliyetli ve çevresel sorunları ortadan kaldıracak yöntemleri tercih edilir duruma getirmiştir. Hatta bu yöntemler zorunlu hale gelmiştir. Atık maddelerin bertarafı sırasında dikkat edilmesi gereken ilk unsur atıkların doğuracağı çevresel etkilerdir. Çevresel sınırlamalar her geçen gün artmakta ve eski bertaraf metotları için verilen izinlerin gittikçe azaldığı görülmektedir. Gelişen teknoloji ile Türkiye'de dâhil olmak üzere pek çok ülkede atık maddelerin kullanımı için aşağıdaki başlıklarda çalışmalar yapılması yönünde kararlar alınmıştır[2].

1. Atığı kaynağında azaltma

2. Yeniden kullanma

3. Geri dönüşümünü sağlama

4. Enerji kazanımı

Atık maddelerin tamamının bertarafı her zaman mümkün olmamakta ve alternatif kullanım alanlarının tercih edilmesi gerekmektedir. İSTAC ve İBB'nin 2010 yılında başlattığ çalışmalar göstermektedir ki kentsel dönüşüm atığı miktarı zaman içinde artış göstermektedir. Kentsel dönüşüm atıklarının yol ve üstyapı inşaatlarında kullanılması bu atıkların bertarafı için önemli bir seçenek olarak görülmektedir[3].

Tablo 1. Yıllar içinde İstanbul'da oluşan hafriyat toprağı ve inşaat ve yıkıntı atık miktarları[5]

\begin{tabular}{lllllll}
\hline Y11 & $\begin{array}{l}\text { ISTAÇ- } \\
\text { miktarı } \\
\text { (milyon ton) }\end{array}$ & $\begin{array}{l}\text { Atık } \\
\text { miktarı } \\
\text { (milyon ton) }\end{array}$ & $\begin{array}{l}\text { İBB- } \\
\text { miktarı } \\
\left.(\text { milyon })^{2}\right)\end{array}$ & $\begin{array}{l}\text { Atık } \\
\left.\text { İSTAÇ / İBB } / \mathrm{m}^{3}\right)\end{array}$ & $\begin{array}{l}\text { İBB /İBB } \\
\left.(\text { ton / })^{3}\right)\end{array}$ \\
\hline 2010 & 23.0 & - & 22.1 & 1.04 & 1.70 \\
2011 & 28.0 & 47.7 & 28.0 & 0.99 & 1.70 \\
2012 & 45.0 & 52.4 & 30.8 & 1.45 & 1.70 \\
2013 & 62.0 & 65.5 & 38.5 & 1.61 & 1.70 \\
2014 & 60.1 & 69.9 & 41.2 & 1.47 & 1.70 \\
2015 & 70.0 & 74.9 & 44.1 & 1.59 & 1.70 \\
2016 & 72.0 & - & 44.3 & 1.62 & 1.70 \\
2017 & 83.4 & - & 53.2 & 1.56 & - \\
2018 & - & - & - & - & - \\
Ort. & - & - & - & 1.61 & 1.70 \\
\hline
\end{tabular}


Yumuşak temel malzemeler üzerinde yapılan yol sisteminin istenilen özellikleri sağlayamadığ1 durumlarda zemininde iyileştirme sistemleri kullanılmaktadır. Literatür çalışmalarında bölgesel şartlar ve kullanım yerlerine göre yol alt dolgularının iyileştirilmesinde birçok yöntem mevcuttur.

- Kireçle Stabilizasyon

- Bitümle Stabilizasyon

- Çimento ile Stabilizasyon

- Baca Külü ve Kireç ile Stabilizasyon

○ Uçucu Kül Katkısı

- Eski Araç Lastiği Katkısı

○ Uçucu Kül ve Çimento Katkısı

- Çimento ve Kireç Katkısı

- Çelikhane Cürufu

$\mathrm{Bu}$ yöntemler yol alt dolgularında oluşan aşırı deformasyonların azaltılmasını sağlamaktadır. Ayrıca inşaat yüklenmesinden sonra temel malzemelerinin zamanla zayıflama potansiyelini de ortadan kaldırmaktadır.

\section{Materyal ve Metot}

Esnek üst yapının projelendirilmesinde, trafik yükünü oturmalar ve çatlamalar olmadan taşıması için dikkat edilmesi gereken faktörler başlıca sıralana bilmektedir.

○ Toplam kalınlığının belirlenmesi,

- Tabakaların tek tek kalınlıklarının hesaplanması,

○ Kullanılacak malzemelerin özelliklerinin saptanması,

○ Trafik hacmi,

○ Dingil yükü ve dingil yüklerinin tekrarlanma sayısı,

- Taban zemininin taşıma gücü ve suya hassasiyeti,

- Üstyapının alt temel, temel ve kaplama tabakalarında kullanılan çeşitli malzemelerin mekanik özellikleri,

○ Yolun hizmet kalitesi ve ekonomik hizmet süresi,

○ Yolun yapıldı̆̆ı yerin iklimi ve diğer bölgesel koşulları,

Zeminin taşıma kapasitesinin iyileştirilmesi zemin iyileştirme yöntemleri ile sağlanabilmektedir. Genel olarak katkı malzemeleri ile karışım tekniği kullanılarak yapılan stabilizasyon, zemine kolay uyum sağlaması yönünden zemin durumunu iyileştirmek için büyük etkiye sahiptir. Günümüzde çevre kirliliği vb. sorunları beraberinde getiren atık malzemelerin kullanılması zorunluluk haline gelmiştir. Atık maddelerin bina ve yol yapımında ve zemin iyileştirmede kullanılması mümkündür. Literatürde atık malzemeler kullanılarak yapılan birçok çalışma bulunmaktadır. Bu çalışma, yumuşak kil üzerine inşa edilme aşamasındaki bir karayolunun ilk inşaat aşamasında karayolunu desteklemek için ahşap kereste kazıklar veya yumuşak kil tabakası yerine inşaat yıkıntı atıkları ile dolgu yaparak iyileştirme işlemlerinin her iki koşul için ayrı ayrı FLAC 2D ile yapılan analiz sonuçlarını içermektedir.

Yapılan analizlerin sonucunda oluşan oturma miktarlarının karşılaştırması yapılmıştır. Nümerik modelde farklı malzemeler ve bunların ilişkili özellikleri tanımlanabilmektedir. 
Zemin özelliklerinin belirlenmesinde sondaj verileri ve laboratuar test sonuçlarından faydalanılmıştır. Nümerik model ile yapılan ilk çalışmalar tabakalı zemin şeklinde modellenerek yapılmıştır.

Daha sonra inşaat yıkıntı atığı ve ahşap kazık destekli genel zemin özellikleri belirlenerek analizler yapılmıştır. Mevcut zemin formasyonu için yapılan ön çalışmalarda kullanılan zemin özellikleri tablo 2'de listelenmiştir. Malzeme özellikleri, zemin tabaka yüklerine ilave olarak $11.500 \mathrm{~Pa}$ trafik yükü eklenmiştir. Yer altı su yoğunluğu $1000 \mathrm{~kg} / \mathrm{m}^{3}$ yer altı suyu kütle modülü $10000 \mathrm{~Pa}$ olarak alınmıştır. Ahşap kazıkların ağırlıkları ihmal edilmiştir. Siltli kum tabakasında kazıkların nihai yapışma mukavemeti 250 kN'luk ek taşıma kapasitesi oluşturmaktadır. Ayrıca kazıkların üst, orta ve alt bölgelerinde 210 kN'luk eksenel yük yüklenmektedir.

Tablo 2 Mevcut zemin özellikleri[1]

\begin{tabular}{llll}
\hline & Yüksek plastiseli kil & Düşük Plastiseli kil & Siltli kum \\
\hline Doygun birim ağırlık $\left(\mathrm{N} / \mathrm{m}^{3}\right)$ & 11,100 & 13,560 & 18,840 \\
Porosity (\%) & 90 & 80 & 30 \\
Kuru birim hacim ağılık $\left(\mathrm{kg} / \mathrm{m}^{3}\right)$ & 231 & 582 & 1620 \\
Young modülü (MPa) & 0,3 & 0,5 & 15,0 \\
Poisson oranı & 0,49 & 0,45 & 0,3 \\
Bulk modulus (MPa) & 5,0 & 1,67 & 12,5 \\
Kayma modülü (MPa) & 0,1 & 0,17 & 5,77 \\
Kohezyon (Pa) & 3500 & 5000 & 0 \\
Sürtünme açısı (derece) & 0 & 0 & 32 \\
Genişleme açısı (degrees) & 0 & 0 & 0 \\
Yatay geçirgenlik (m/day) & 0,003 & 0,0003 & 2,4 \\
Dikey geçirgenlik (m/day) & 0,001 & 0,0001 & 0,8 \\
\hline
\end{tabular}

İnşaat yıkıntı atıkları ve alt yapı dolgu malzemesinin özellikleri tablo 3' te işlem görmüş kereste kazıkların özellikleri tablo 4'te verilmiştir.

Tablo 3 Dolgu malzemelerinin özellikleri[1-5]

\begin{tabular}{lll}
\hline & Yol alt dolgusu & İnşaat yıkıntı atığ1 \\
\hline Kuru birim hacim ağırlık $\left(\mathrm{kg} / \mathrm{m}^{3}\right)$ & 1920 & 1920 \\
Porosity $(\%)$ & 30 & - \\
Young modülü $(\mathrm{MPa})$ & 10,0 & 111,141 \\
Poisson oranı & 0,3 & 0 \\
Bulk modulus $(\mathrm{MPa})$ & 8,33 & 138,926 \\
Kayma modülü $(\mathrm{MPa})$ & 3,85 & 24,161 \\
Kohezyon $(\mathrm{Pa})$ & 2400 & 49,000 \\
Sürtünme açısı (derece) & 30 & - \\
Yatay geçirgenlik (m/day) & 1,2 & 1,2 \\
Düşey geçirgenlik (m/day) & 0,4 & 0,4 \\
\hline
\end{tabular}


Tablo 4 İşlenmiş kereste kazıkların özellikleri[1]

\begin{tabular}{lll}
\hline Elastisite modülü $(\mathrm{GPa})$ & 10,0 & \\
Kazık taşıma kapasitesi $(\mathrm{kN})$ & 250,0 & \\
Kazık uzunlukları $(\mathrm{m})$ & 12,8 & \\
Ortalama kazı çapı $(\mathrm{m})$ & 0,3048 & Üst ve alt bölüm \\
& Orta Bölümler & 10,0 \\
Young modülü (GPa) & 10,0 & 0,1524 \\
Yarıçap (m) & 0,1524 & 0,976 \\
Çevre (m) & 0,976 & 2,5 \\
Aralık (m) & 2,5 & 1,0 \\
Yay makaslama direnci $(\mathrm{GN} / \mathrm{m} / \mathrm{m})$ & 0,0 & 2,5 \\
Yay makaslama kohezyonu $(\mathrm{MN} / \mathrm{m})$ & 0,0 & 0,0 \\
Yay makaslama açısı (derece) & 0,0 & \\
\hline
\end{tabular}

\section{Analiz Sonuçları}

Zemin koşulları bilinen bir yol güzergâhına trafik yükünün de etki etmesi ile oluşabilecek düşey yer değiştirmeler ve boşluk suyu basınçları model üzerinde belirlenen koordinatları temsil eden noktalarda incelenmiştir (şekil 1). Dolgu üstü boyunca, 1-2-3-4 numaralı ve dolgu tabanı boyunca 5-6-7-8 numaralı noktalarda düşey yer değiştirmeler, 8-9-10-11 numaralı noktalarda ise boşluk suyu basıncı yol inşaatı boyunca izlenmiştir.

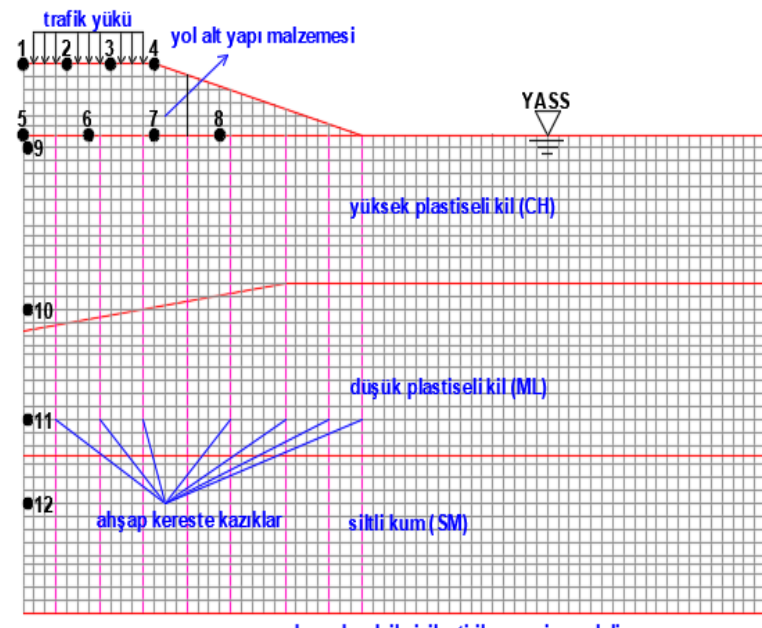

a. ahşap kazık ile iyileştirilen zemin modeli

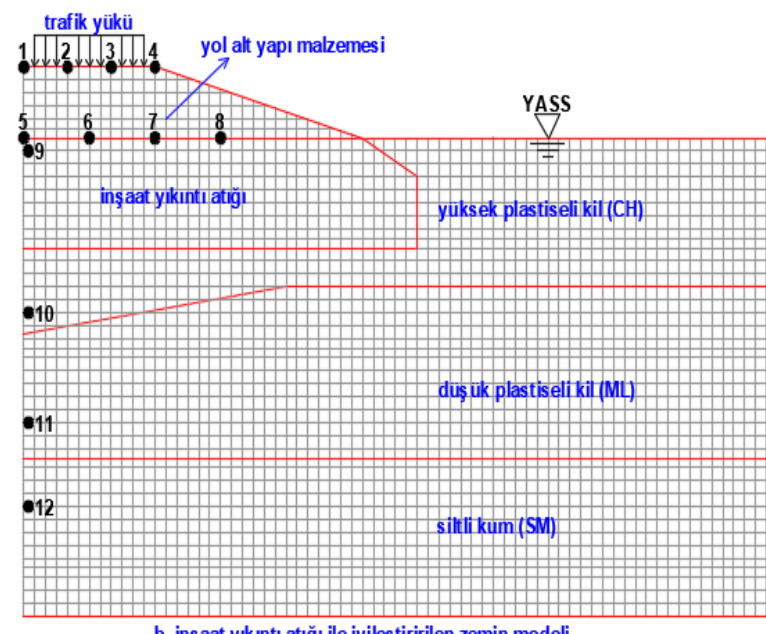

b. inşaat yıkıntı atığı ile iyileştiririlen zemin modeli

Şekil 1 Nümerik modeller ve okuma noktaları

\subsection{Mevcut saha zemin tabakalarının analizi}

Nümerik Modelleme ve laboratuvar analizlerinde elde edilen sonuçların değerlendirilebilmesi için mevcut koşulların analizlerinin de yapılması gerekmektedir. Bu aşamada elde edilen sonuçlar mevcut zeminin iyileştirme öncesi performansını ortaya koymaktadır. Böylece zemin iyileştirme sonunda ortaya çıkacak performansın değerlendirmesi yapılabilmektedir. Çalışmanın bu bölümünde mevcut zeminin iyileştirme öncesi analizleri yapılmış ve muhtemel düşey yer değiştirmeler elde edilmiştir. Mevcut saha şartları modellenmiş ve yapılan analizler sonucunda maksimum düşey yer değiştirme dolgunun altında yaklaşık $57 \mathrm{~cm}$ 'dir. Dolgunun üst kısmında dolgu ağırlığının olmaması sebebi yer değiştirme daha az olmuştur. 
Dolgunun üst kısmına etki eden tek yükün trafik yükü olduğu noktalarda ilk 0,8 saniyede düşey yer değiştirme gerçekleşmemiştir. Analiz sonuçları incelendiğinde, trafik yükü ilk 0,8 saniyede boşluk suyu basıncında değişiklik yapabilecek bir etki oluşturamamıştır.

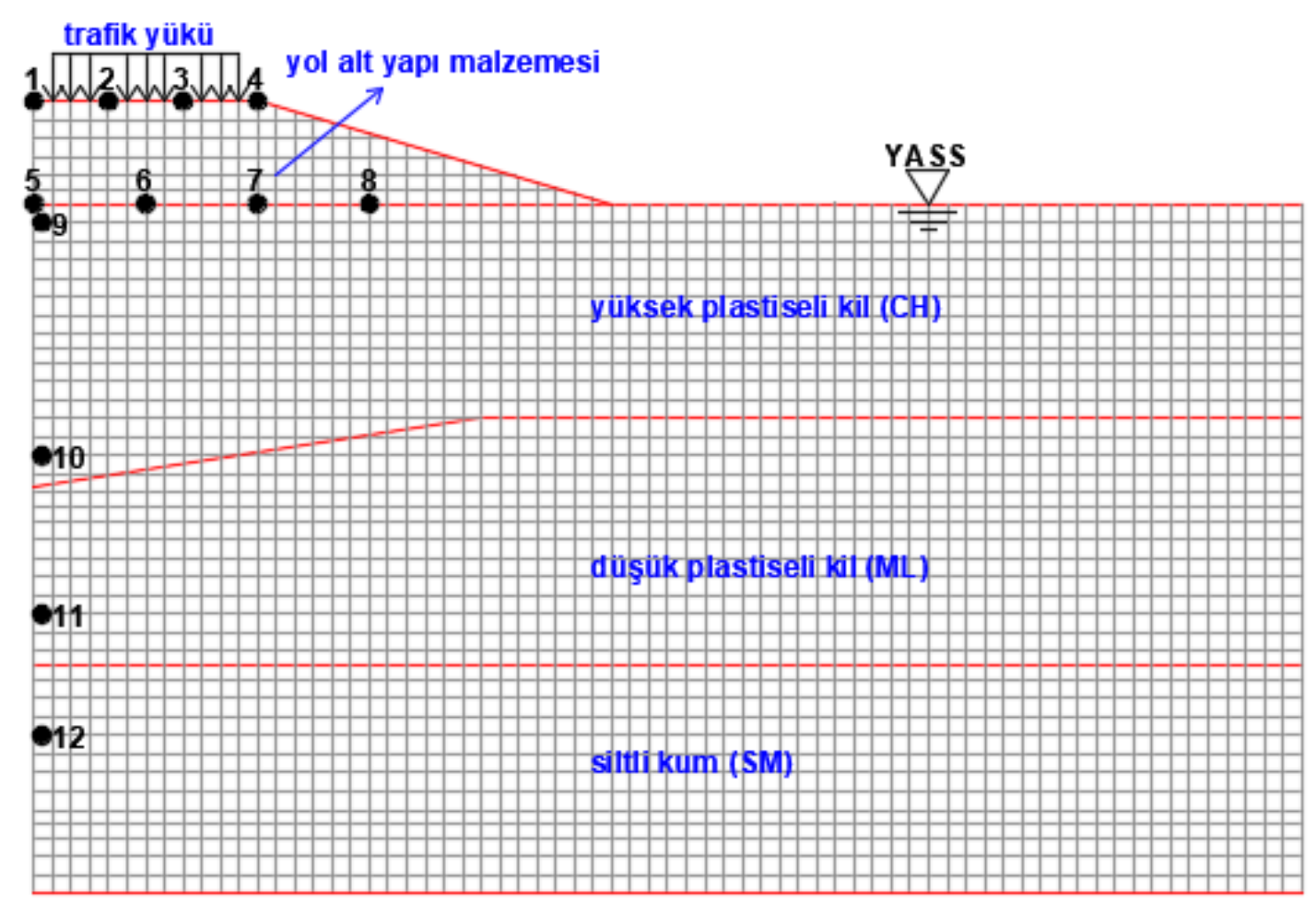

Şekil 2 Mevcut zemin numerik model ve okuma noktaları

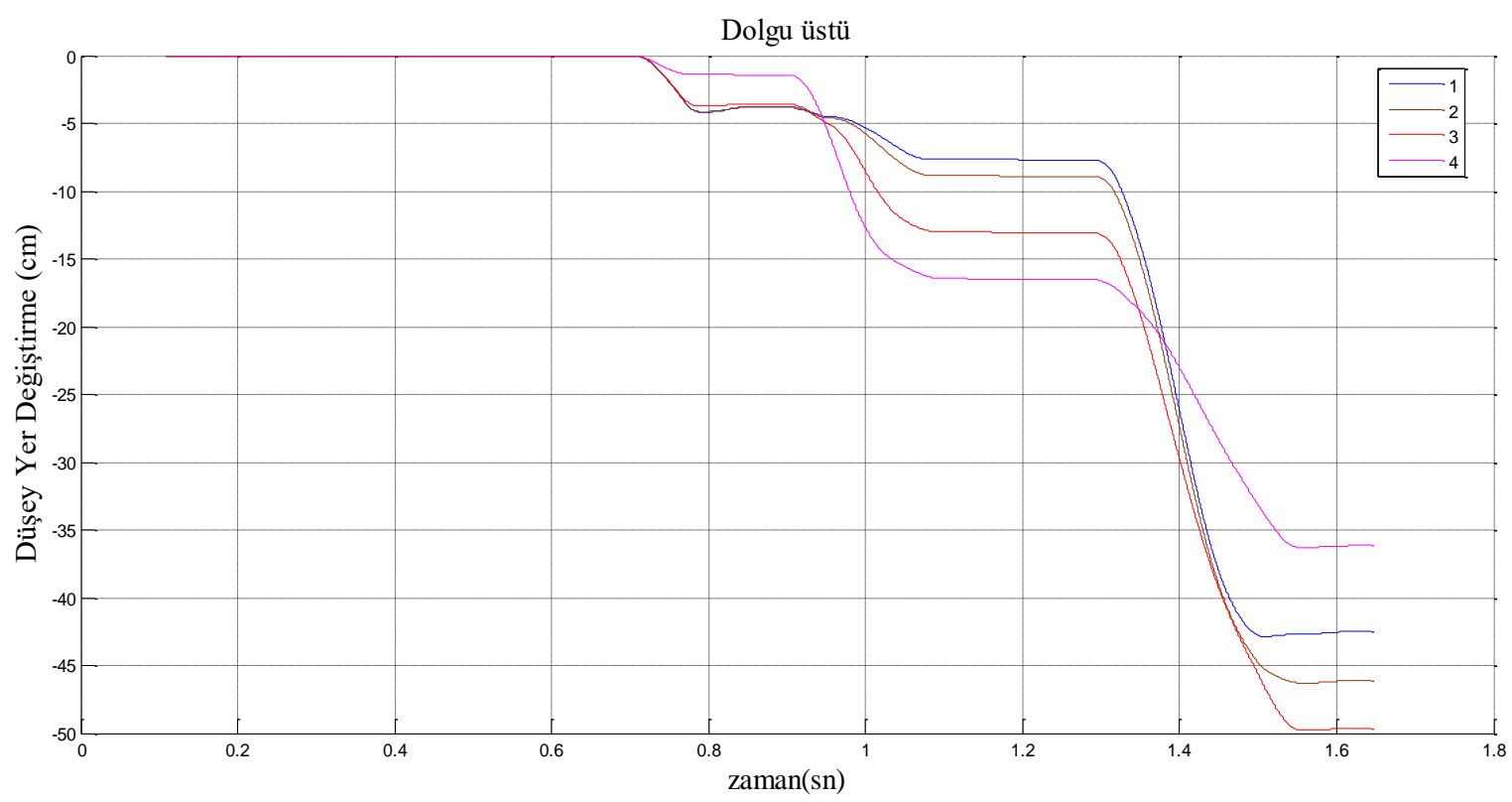

Şekil 3 Mevcut zemin dolgu üstü düşey yer değiştirme 


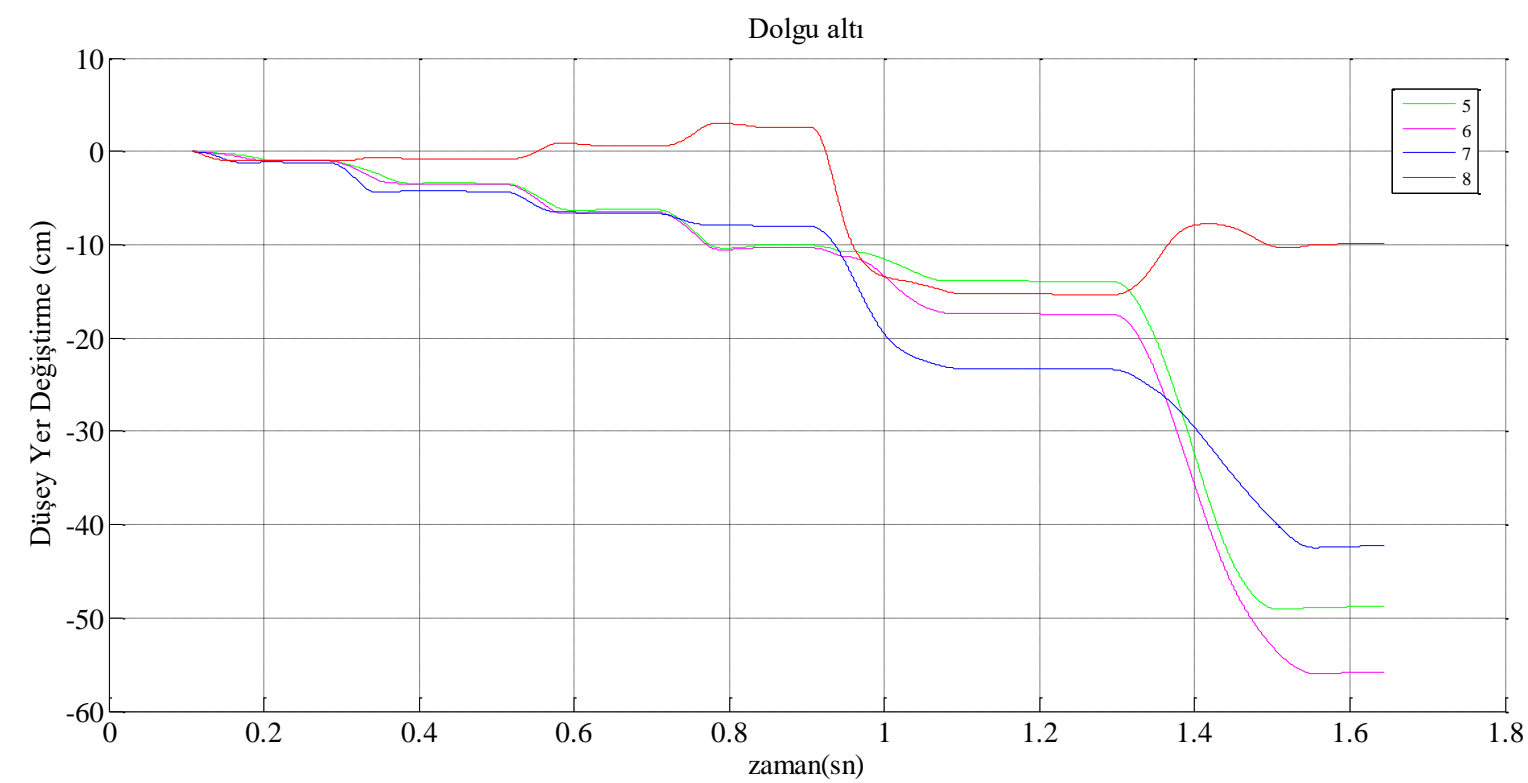

Şekil 4 Mevcut zemin dolgu altı düşey yer değiştirme

Zemindeki oturma miktarına boşluk suyu basıncının etkisi vardır. Boşluk suyu basıncına dış yük altındaki zeminde bulunan yer altı suyunun zemin içerisindeki boşluklarda oluşturduğu zemin direnç kaybı diyebiliriz. Zemindeki oturma miktarının fazla olması $\mathrm{CH}$ ve ML tabakalarındaki boşluk suyu basıncı ile ilişkilidir. FLAC 2D analizleri sonucunda farklı derinliklerde belirlenen boşluk suyu basınç değerleri şekil 5' te gösterilmektedir.

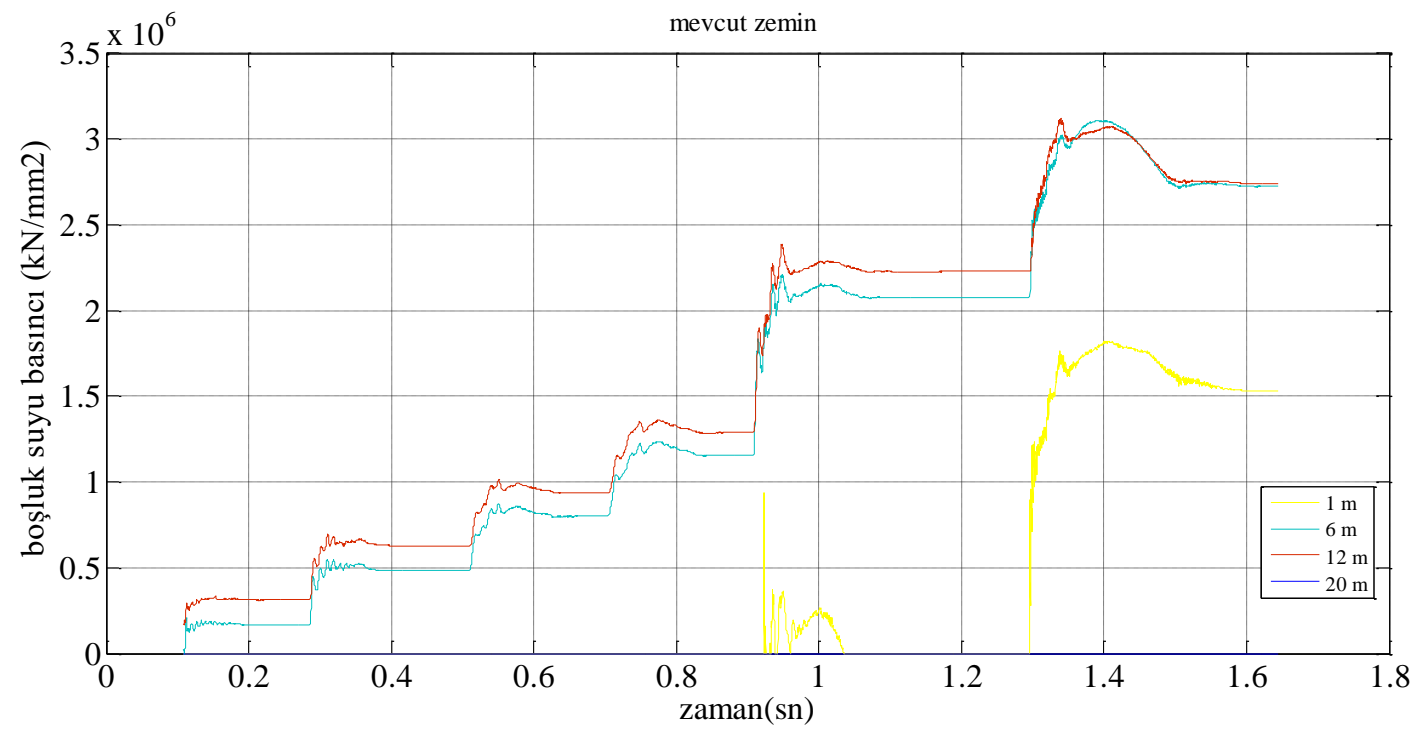

Şekil 5 Boşluk suyu basıncı

\section{2. İnşaat yıkıntı atığı ile iyileştirilmiş zemin analizleri}

Yumuşak kil tabakalarındaki oturma problemlerini çözmek ve gevşek kumlarda sıvılaşma riskinin azaltılması için iyileştirme yöntemi kullanılmaktadır. Bu çalışmada yol dolgusunun alt kısmındaki yüksek plastiseli kil $(\mathrm{CH})$ tabakası kaldırılmış taşıma gücü daha fazla olan yıkıntı atıkları ile iyileştirme işlemi yapılmıştır (şekil 6). Literatürde yıkıntı atıklarını da içeriğinde bulunduran zemin örnekleri ile yapılan çalışmalarda iyileşme sağlandığı görülmüştür.[2] 


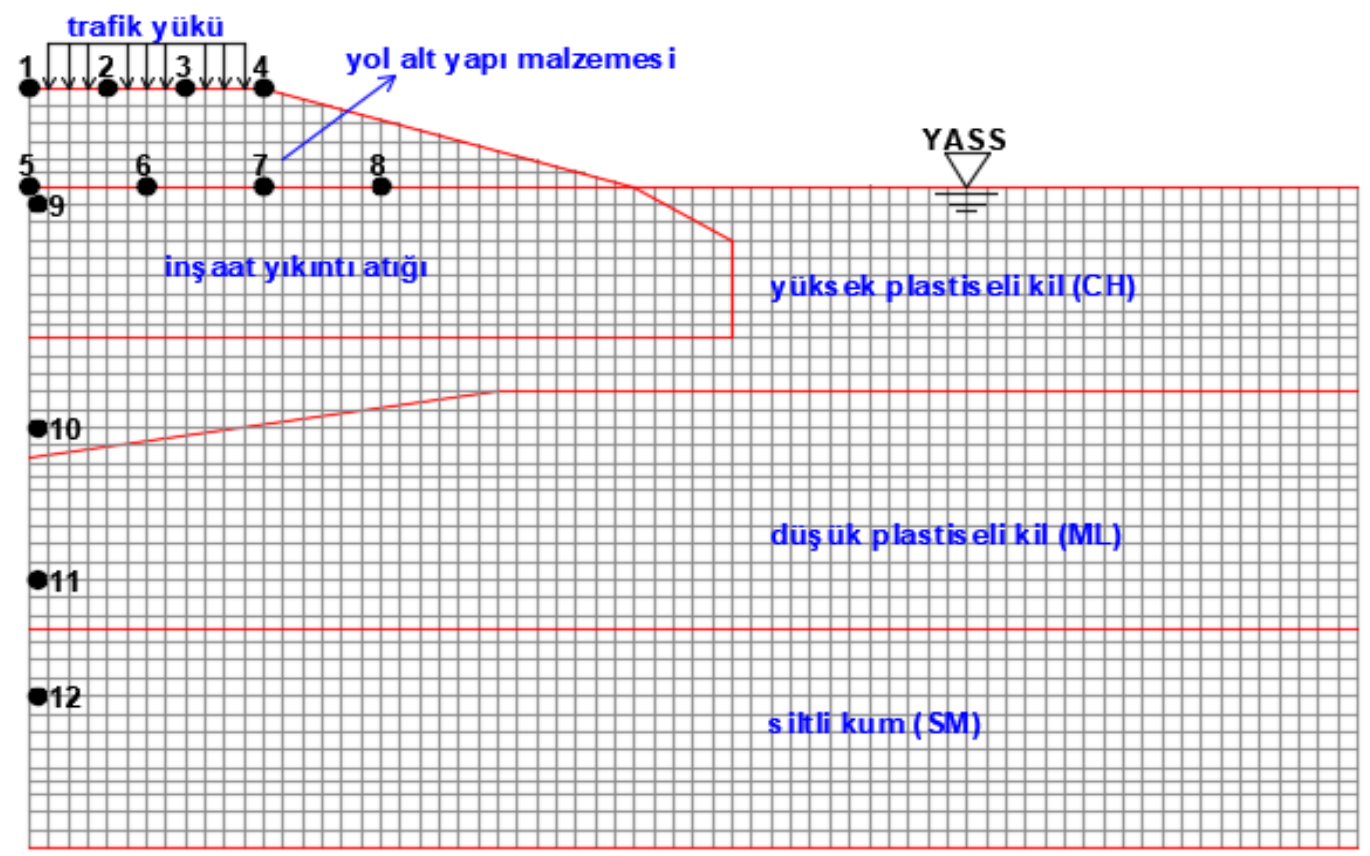

Şekil 6 Kentsel dönüşüm atıkları ile iyileştirilmiş zemin modeli

FLAC 2D sonlu farklar metodu ile kurulan modelde yapilan analiz sonucu yol alt dolgusundaki düşey yer değiş̧irme miktarında azalma görülmüştür (şekil 7-8). Maksimum yer değiştirme yol alt dolgusunun altında $8,5 \mathrm{~cm}$ gözlemlenmiştir.

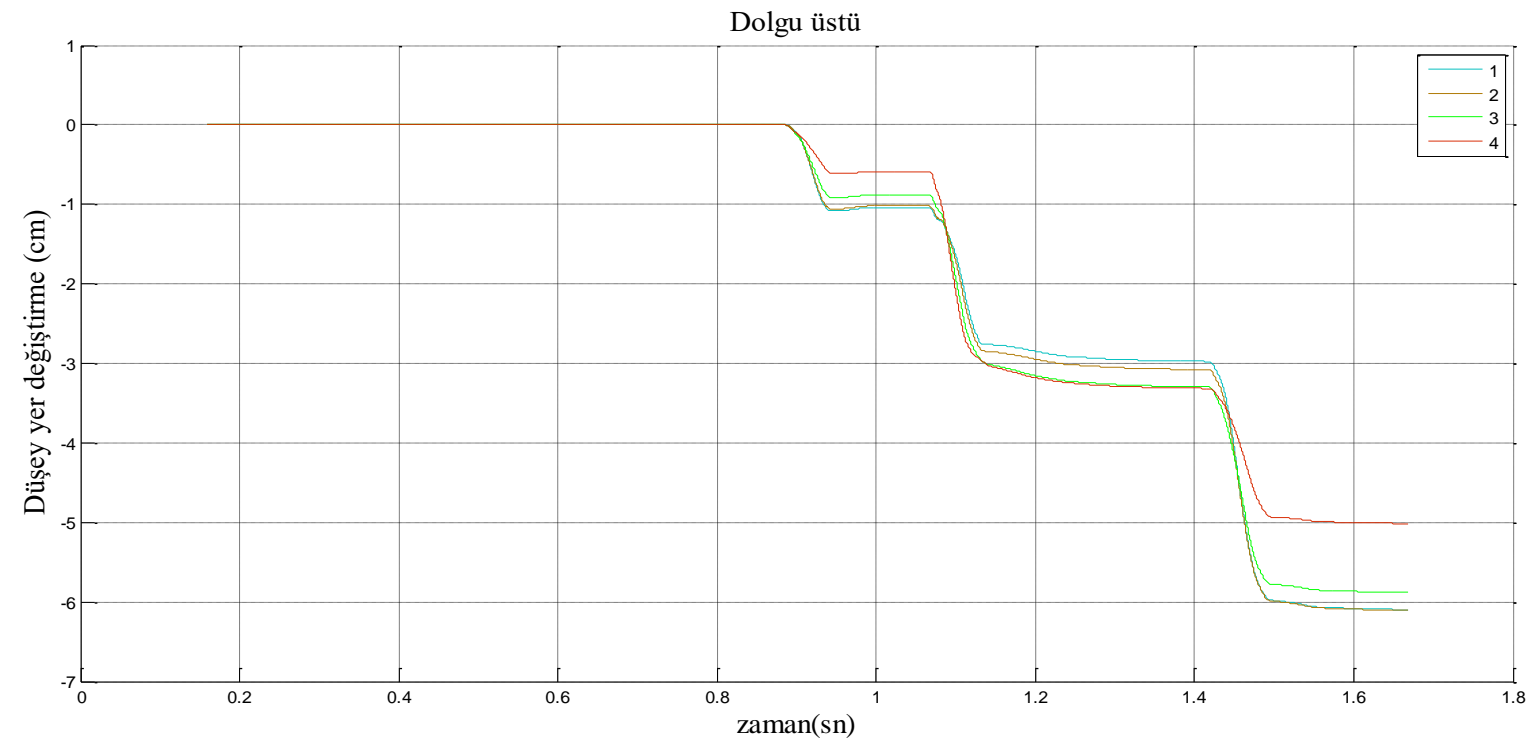

Şekil 7 İnşaat yıkıntı atıkları ile iyileştirilmiş zemin dolgu üstü düşey yer değiştirme 


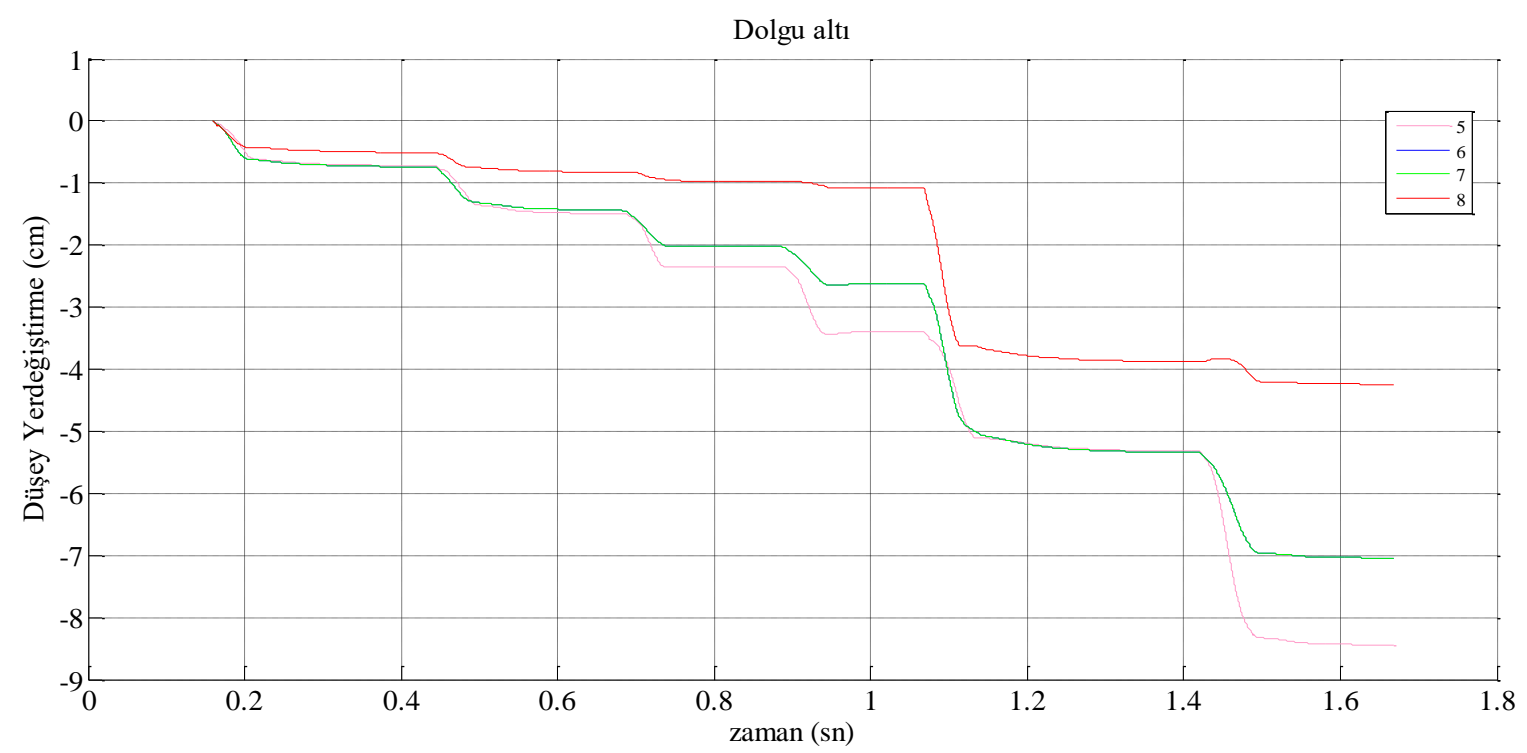

Şekil 8 İnşaat yıkıntı atıkları ile iyileştirilmiş zemin dolgu altı düşey yer değiştirme

İnşaat yıkıntı atıkları ile iyileştirilen zemindeki boşluk suyu basınç değerleri Şekil 9' da verilmiştir. Dinamik yük etkisi altında zemin suyu, zemin boşluklarından hızla uzaklaşamadığı için zeminin boşluk suyu basıncını artırmakta ve tanelerle sıvı ilişkisini koparmaktadır. Yani tanelerin sürtünmeyle taşıyacakları yük sıfıra düşmektedir. [8] Bu da temel altındaki zeminin mukavemetini düşürmekte ve oturma miktarlarında artış gözlenmektedir. Yıkıntı atıkları ile yapılan iyileştirme sonucunda boşluk suyu basıncında artış gözlenmiştir. $\mathrm{Bu}$ artışa zıt olarak zemindeki oturma miktarında azalma olmuştur.

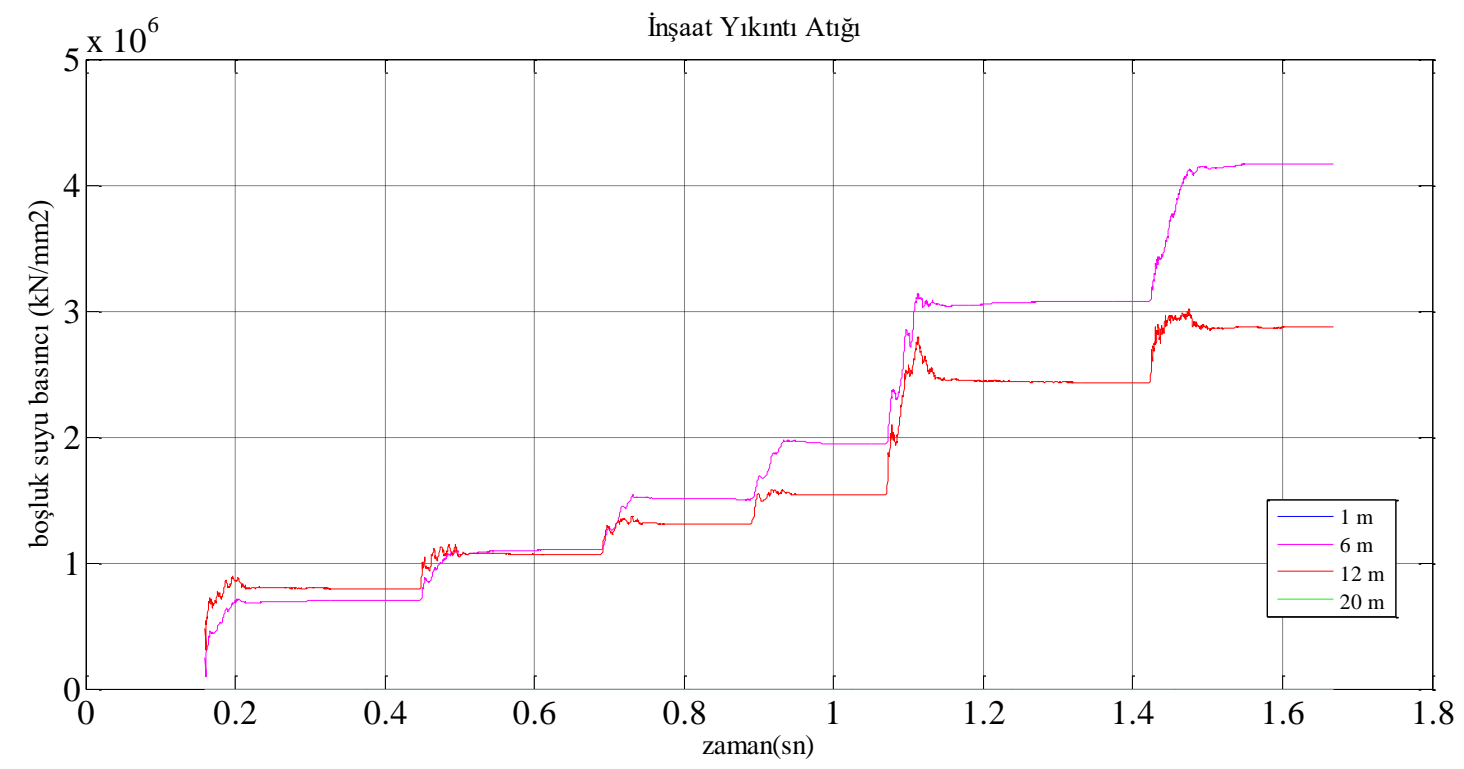

Şekil 9 Yıkıntı atı̆̆ı boşluk suyu basıncı 


\subsection{Kazık destekli zemin analizi}

Kazık destekli sitemler ile zemin iyileştirme eski medeniyetlerden beri kullanılmaktadır. $\mathrm{Bu}$ çalışmada yol alt dolgusuna ahşap kazıklar ile zemin desteği sağlanmıştır. Kazık destekli sistemlerde kazıkların konumu ve boyutları önemlidir.

Numerik modelde ahşap kazıklardan $250 \mathrm{kN}$ 'luk bir taşıma kapasitesi sağlamak için $2.5 \mathrm{~m}$ aralıkta eksenel olarak kazıklar yerleştirilmiştir (şekil 8).

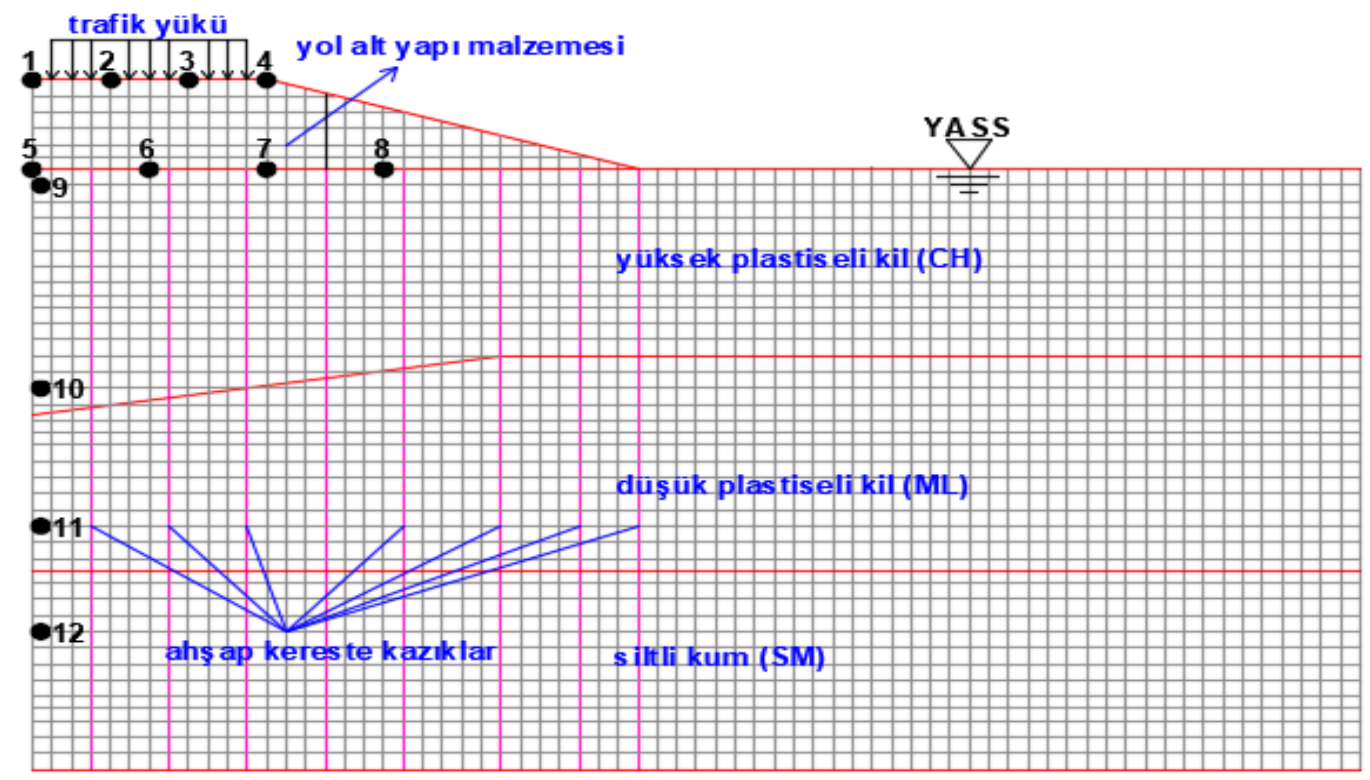

Şekil 10 Kazık desteklenen sistemin numerik model

Ahşap kazık destekli karayolunda dikey yer değiştirmeler şekil 11 ve şekil 12' de gösterilmektedir. Dolgunun altındaki maksimum dikey yer değiştirme yaklaşık 4,5 cm'dir.

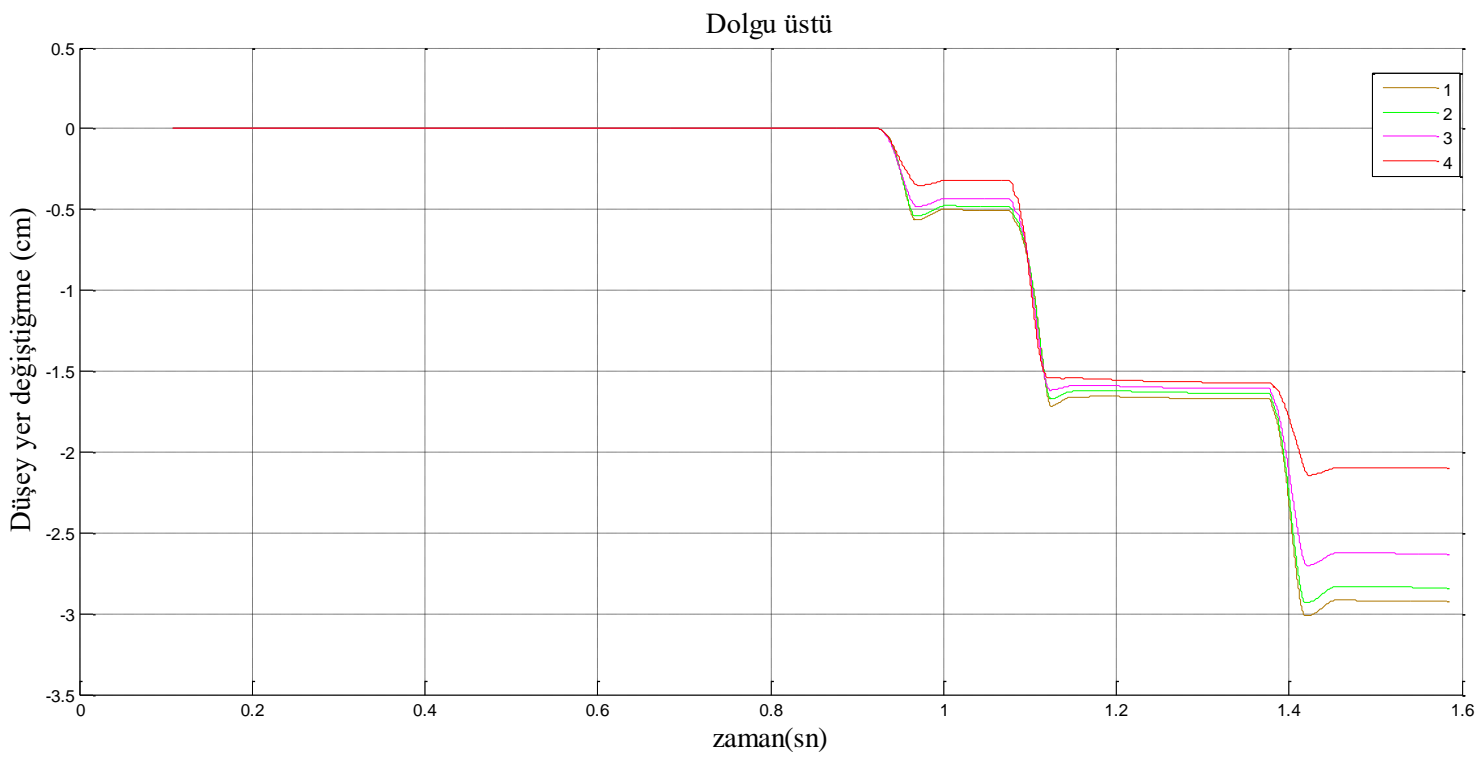

Şekil 11 Kazık destekli sistemde dolgu üstü düşey yer değiştirme miktarı 


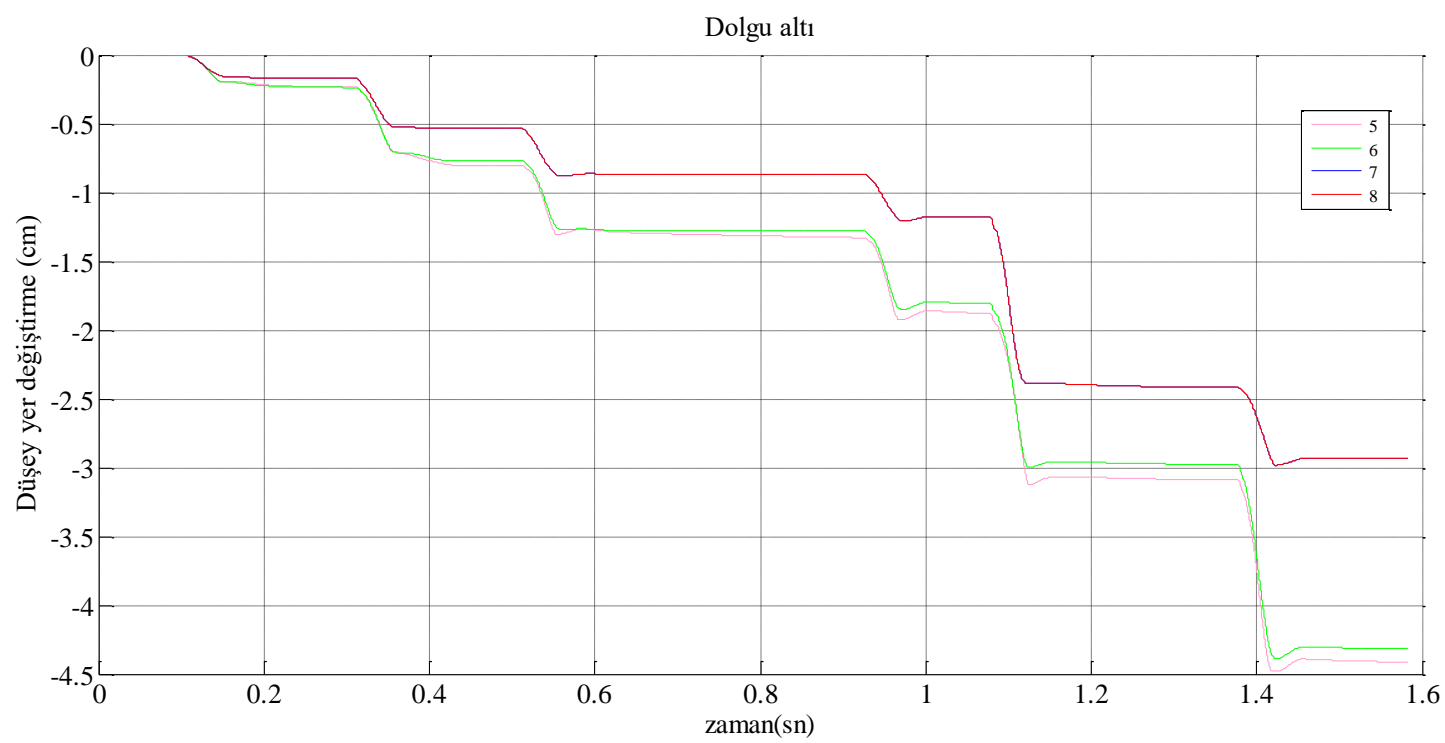

Şekil 12 Kazık destekli sistemde dolgu altı düşey yer değiştirme miktarı

Yüksek plastiseli kil ve düşük plastiseli kildeki gözenek basınçlarında önemli bir değişiklik olmamıştır. Bu durum Şekil 13' de gösterilmiştir.

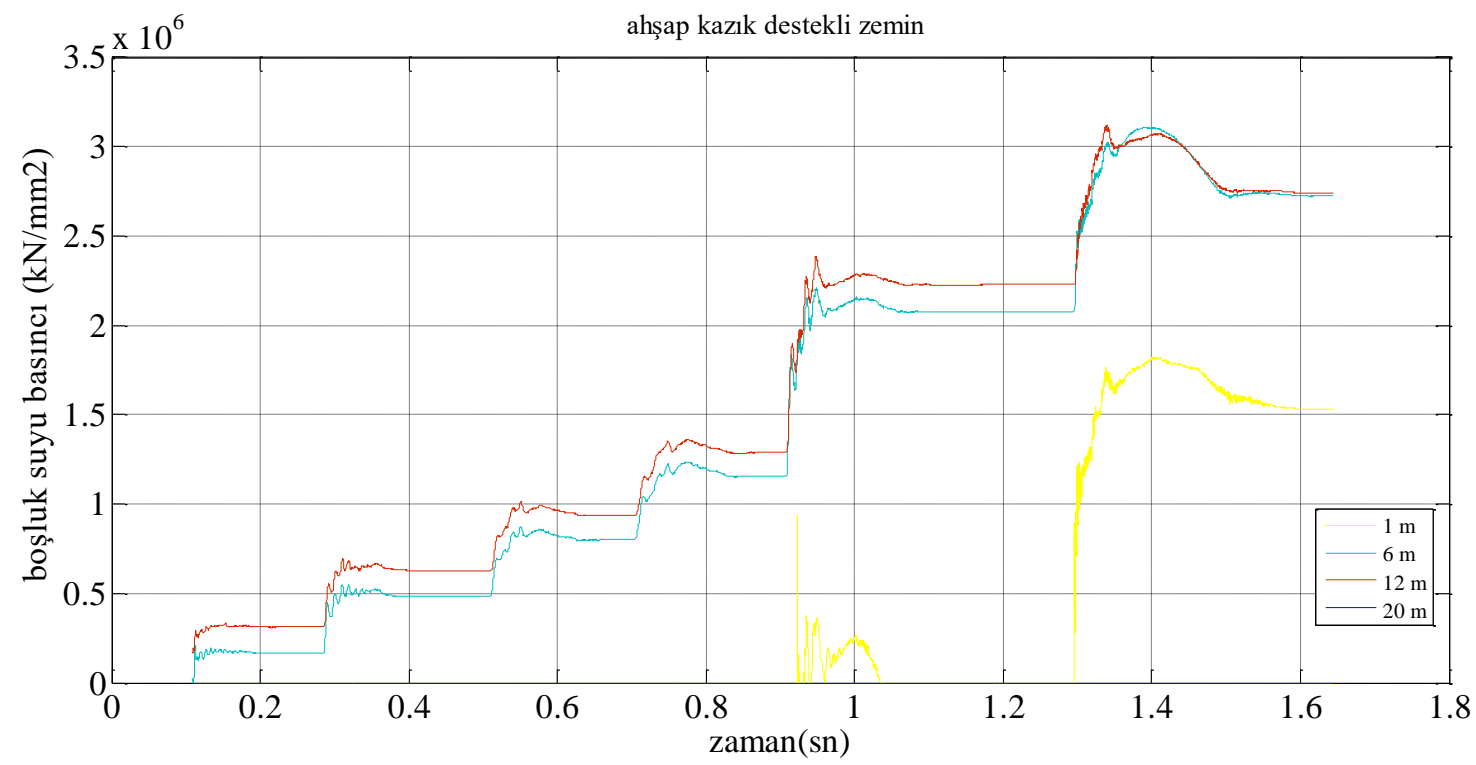

Şekil 13 Kazık destekli karayolu gözenek basıncı

\subsection{Analiz Sonuçlarının Karşılaştırılması}

Zayıf zeminde $57 \mathrm{~cm}$ olan yer değiştirme, inşaat yıkıntı atığ 1 ile iyileştirilen zeminde $9 \mathrm{~cm}$, ahşap kazık ile desteklenen zeminde $4,5 \mathrm{~cm}$ görülmüştür. Kereste kazıklar ile yapılan iyileştirme sonucunda boşluk suyu basıncında her hangi bir değişiklik olmamıştır. Geçirimliliğin azalmasına sebep olan yıkıntı atıklarının kullanıldığı iyileştirme sonucunda boşluk suyu basıncında artış gözlemlenmiştir. 


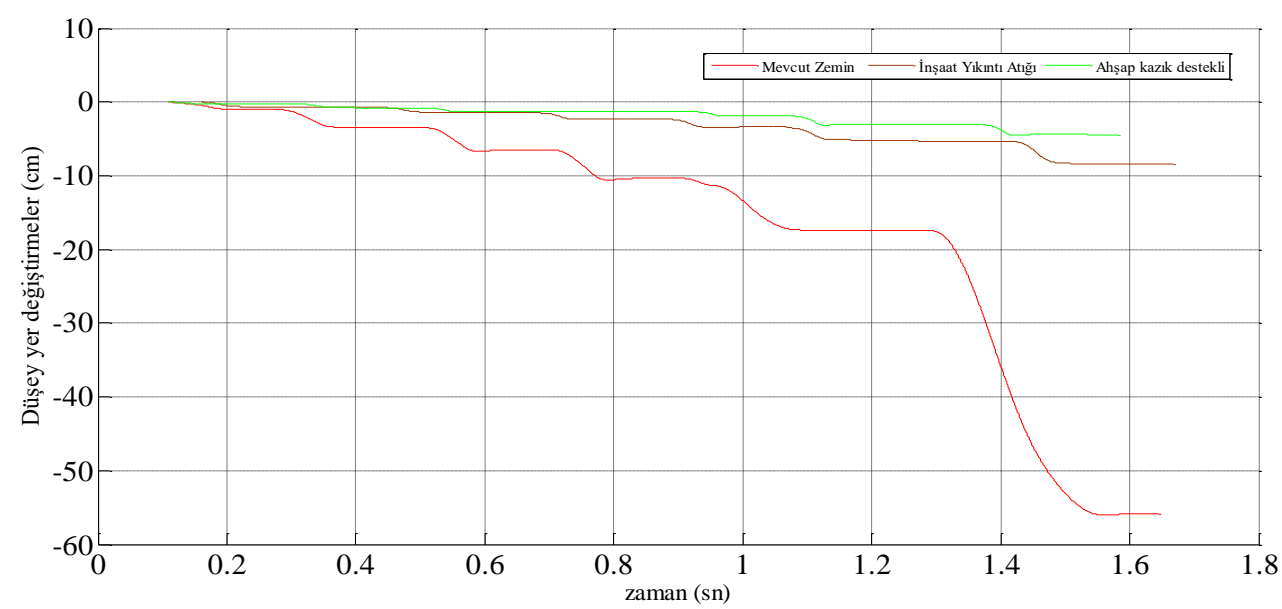

Şekil 14 Mevcut zemin ve iyileştirme yöntemine göre zemindeki maksimum oturma miktarları

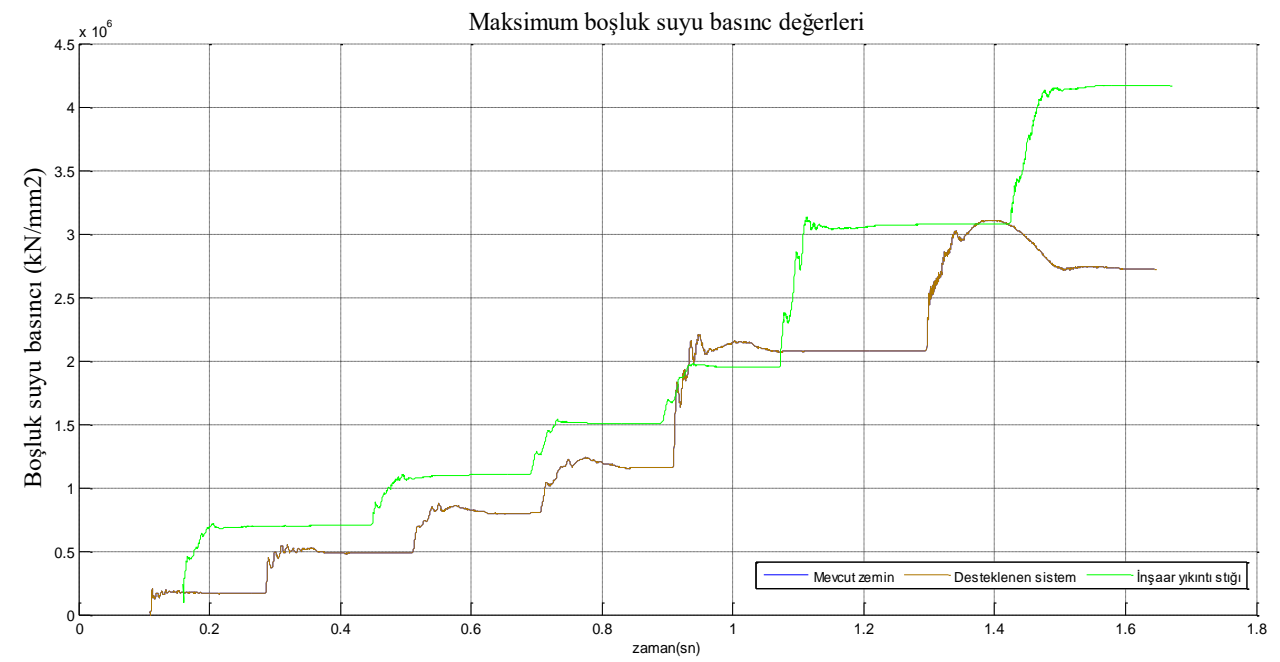

Şekil 15 Mevcut zemin ve iyileştirme yöntemine göre zemindeki maksimum boşluk suyu basıncı miktarları

\section{Sonuçlar}

Yol yapım çalışmalarında çeşitli yol kesimlerinde zemin gerekli dayanımı göstermemektedir. $\mathrm{Bu}$ durumda taşıma gücü istenilen değerde olmayan zemin bölgeleri için iyileştirme işlemi yapılması gereklidir. Çalışmada yapılan nümerik model analizlerine göre üç farklı koşulda gerçekleşen maksimum düşey yer değiştirme değerleri incelenmiştir ve iyileştirme yapılmayan zeminde $57 \mathrm{~cm}$ olduğu belirlenmiştir.

İnşaat yıkıntı atığı ile iyileştirilen zeminde \% 84 olan iyileşme, ahşap kazık ile desteklenen zeminde \% 95 olarak görülmüştür. Literatürdeki zemin iyileştirme yöntemlerinin farklı avantaj ve dezavantajları olmaktadır. Elde edilen sonuçlara göre;

1. Ahşap kazık destekli sitemin oturma miktarındaki iyileşme oranı, inşaat yıkıntı atıkları ile iyileştirilen zemine göre daha fazla olmuştur.

2. Ahşap kerestelerin temin edilmesi sürecinde doğaya zarar veriliyor olmasına karşılık, atık malzemenin kullanılması ile kentsel dönüşüm ve artan nüfus sonucu kentlerde oluşan çevresel kirlilik ve oluşabilecek sağlık sorunları azalmaktadır. 
3. Kerestelerin işlenerek istenilen boyutlara getirilmesi ve uygulama işlemlerinin oluşturduğu maliyete karşılık, yıkıntı atıklarının kazı ve dolgu gibi maliyeti düşük işlemler ile uygulanabilmesi.

4. Yıkıntı atıklarının kullanımı ile bazı doğal kaynakların azalmasının engellenebilir olmasi.

5. Kentsel dönüşüm atıklarının depolanması için ayrılan alanların, çevreye kazandırılması ve getirisi daha yüksek projeler için kullanılabilmesine imkân sağlanmasi

Nümerik model analizlerine göre elde edilen değerler, literatür çalışmaları ve tüm sonuçlar bir bütün olarak değerlendirildiğinde şehir ve çevre kirliliğine neden olan, depremde yıkılan, ağır hasar gören inşaat atıkları ile kentsel dönüşüm kapsamında yıkılan yapılara ait inşaat ve yıkıntı atıklarının zemin iyileştirmelerinde kullanılabileceği tespit edilmiştir.

\section{Kaynaklar}

[1] Zorluer İ. - Usta M. Zeminleri Atık Mermer Tozu ile İyileştirilmesi Türkiye 1v Mermer Sempozyumu (Mersem 2003) Bildirimler Kitabı 18-19 Aralık 2003

[2] Öntürk K. - Fırat S. - Vural İ. - Khatip J.M. Uçucu Kül ve Mermer Tozu Kullanılarak Yol Alt Yapısının İyileştirilmesi Politeknik Dergisi Cilt:17, Sayı : 1 (Özel Sayı), S.35-42, 2014

[3] Maçin K.E. - Demir İ. Kentsel Dönüşüm Sürecinde İstanbul'da İnşaat ve Yıkıntı Atıkları Yönetimi Adıyaman Üniversitesi Mühendislik Bilimleri Dergisi 9 (2018) 188-201

[4] Fast Lagrangian Analysis Of Continua Online Manual Table Of Contents

[5] Vural İ. İnşaat Yıkıntı Atıklarının Zemin İyileştirmesinde Kullanılabilirliği. Academic Platform Journal Of Engineering And Science 7-1, 01-06, 2019

[6] Numerical Modeling Of Liquefaction And Comparison With Centrifuge Tests, Canadian, Geotechnical Journal, Vol. 41 (2):193-211, 2004.

[7] Vural İ. İnşaat Yıkıntı Atıkları ile Zeminlerin Taşıma Gücü Özelliklerinin İyileştirmesi 2016 Published İn 4th İnternational Symposium On Innovative Tecnologies in Engineering And Scicene 3-5 November 2016 (Isites2016 Alanya/Antalya-Turkey)

[8] Çetin Y.A. Yüksek Plastisiteli Kil Zeminlerin Alternatif Malzemeler ile Yüzeysel Zemin Stabilizasyonu İstanbul Teknik Üniversitesi Haziran 2011

[9] Pulat H. F. - Aksoy Y. Y. Türkiye Kentsel Katı Atık Kompozisyonunun Kayma Mukavemeti Özellikleri ve Şev Duyarlılığının İncelenmesi Article in Teknik Dergi · January 2017 Do1: 10.18400/Tekderg.299128

[10] Klıç H. Geoteknik Mühendisliğinde Sayısal Analizler Notları 03 Aralık 2017

[11] Mazak E. Kazık Grup Davranışının 2D ve 3D Olarak Araştırılması Uygulamalı Yerbilimleri Dergisi Cilt: 16, No: 2, 2017 (1-11)

[12] Çinicioğlu S.F. Zeminlerde Statik ve Dinamik Yükler Altında Taşıma Gücü Anlayışı ve Hesabı Seminer İMO İstanbul 19.02.2005 